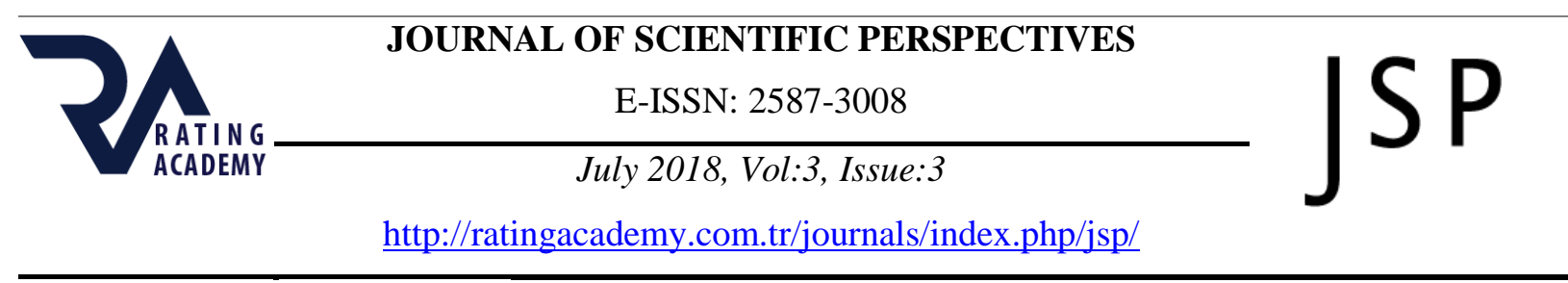

\title{
EVALUATION OF SWELLING PROPERTIES OF POLY (ACRYLIC ACID)/Zr-PILLARED K10 SUPERABSORBENT HYDROGEL*
}

Dr. Zehra BEKÇİ MOLU

Niğde Ömer Halisdemir University, Faculty of Education, Mathematics and Science Education, Science Education, Central Campus, Niğde, Turkey

E-mail: zmolu@ohu.edu.tr

\begin{tabular}{|c|c|}
\hline ARTICLE INFO & ABSTRACT \\
\hline $\begin{array}{l}\text { Article History: } \\
\text { Received: 02July } 2018 \\
\text { Accepted: } 13 \text { July } 2018\end{array}$ & $\begin{array}{l}\mathrm{Zr} \text { - Pillared K10 (Zr-K10) was synthesized by using Montmorillonite K10 clay. } \\
\mathrm{Zr} \text { - pillared K10 based superabsorbent (Zr-PILC-SA) was synthesized by using } \\
\mathrm{Zr} \text {-pillared-montmorillonite K10 via graft copolymerization reaction of acrylic } \\
\text { acid }(A A) \text {. After preparation of the films of hydrogels of } \mathrm{Zr} \text { - pillared K10, }\end{array}$ \\
\hline $\begin{array}{l}\text { Keywords: hydrogel, } \\
\text { superabsorbent composite, } \\
\text { swelling, pH sensitivity, } \\
\text { pillared clay. }\end{array}$ & $\begin{array}{l}\text { swelling studies were performed in distilled water and different } p H \text { values at } \\
\text { room temperature to investigate swelling behavior of pillared clay based } \\
\text { superabsorbent films. It was also obtained that } \mathrm{Zr-K10} \text { based superabsorbent } \\
\text { was } p H \text { dependent and showed a reversible swelling behavior. The swelling }\end{array}$ \\
\hline $\begin{array}{l}\text { DOI: } \\
\text { 10.26900/jsp.2018342241 }\end{array}$ & $\begin{array}{l}\text { behavior of Zr-K10-SA was increasing by decreasing amount of Zr-K10 in the } \\
\text { hydrogel. SEM, FTIR and XRD analysis were conducted for further } \\
\text { characterization of the Zr-PILC-SA. FTIR analyses lead to ester formation } \\
\text { between Zr-K10 and SA. XRD revealed the morphology of the superabsorbent } \\
\text { was exfoliated and the layers of clay dispersed on the composite. }\end{array}$ \\
\hline
\end{tabular}

\section{INTRODUCTION}

Superabsorbents are capable of absorbing and retaining huge amounts of aqueous fluids even under some pressure (Wang et al., 2008). Superabsorbent polymers are used mainly as absorbents in healthcare and agriculture applications and are commonly based on acrylic monomers such as acrylamide, acrylic acid (AA) (Li et al., 2004). However, most of the superabsorbents used as disposable materials are expensive synthetic polymers (Li et al., 2004, Lin et al., 2001), their production consumes a lot of petroleum resource and their usage can also cause a non-negligible environment problem (Wu et al., 2000). Thus the utilization of low-cost resources for preparing superabsorbent and the design and synthesis of multicomponent superabsorbent based on natural materials have been subjects of great interest (Zhang et al., 2006, Weaver et al., 1976). Adding inorganic materials was caused decrease cost amount in production of superabsorbent hydrogels. Pillared clay was used as additive material in the synthesis to decrease production cost of hydrogels in this study.

Pillared clays are layered materials prepared by the exchange of compensating cations for oligomeric or polymeric hydroxymetals, followed by calcination. The calcination promotes the dehydration and dehydroxylation of the polycations, with the formation of metal

\footnotetext{
* The first version of this paper is presented in the "2nd International Rating Academy Congress: Hope" held in Kepez / Çanakkale on April 19-21, 2018.
} 
oxides that act as pillars, maintaining the separation between the layers with the appearance of interlayer and interpillar spaces with molecular dimensions (Figueras, 1988, Vaughan, 1988, Gil, et al., 2000, Cheng, Yang, 1997). The first step in the pillaring process is to prepare a pillaring agent. Zr-pillared clays (Zr-PILCs) were prepared from zirconyl chloride solutions. For synthesis of pillared clay catalysts, Montmorillonite K10 (K10) was used as precursor material. In this study, zirconium pillared montmorillonite K10 samples were prepared for synthesis poly (acrylic acid)/Zr-pillared clay superabsorbent composites. Using Zr-pillared K10 as additive of superabsorbents is the new approach. The preparation of superabsorbent composites is beneficial owing to develop mechanical and materials properties because of negative features such as high production cost and low gel strength. Additionally, clays have been more suitable for use in water absorbents as additives because of their hydrophilic nature. The swelling behavior of polymer/clay superabsorbent composites in water were studied and organic solvents has rarely been discussed.

The present study deals with the synthesis and characterization of $\mathrm{Zr}-\mathrm{K} 10$ and $\mathrm{Zr}$ PILC containing acrylic based superabsorbent hydrogel composites. The effect of $\mathrm{pH}$ values on the water absorbency of the superabsorbent composites containing Zr-K10 was investigated. Moreover the performance of inorganic filler amount on the properties of the superabsorbents was compared each other in detail. Additionally, the characterization of pillared clays containing acrylic-based superabsorbent hydrogel composites was carried out by XRD, FT-IR, and SEM.

\section{MATERIAL AND METHODS}

\subsection{Reagents and Materials}

Acrylic acid (AA) monomer and the crosslinker N, N'-methylene-bisacrylamide (MBA) purchased from Fluka were used without further purification. Ammonium persulfate (APS), sodium metabisulfite (SMBS) and potassium hydroxide (KOH) (all from Merck) were used as received.

Montmorillonite K10 (K10) used in this study was supplied from Fluka Company (Cat. No. 69867) was utilized as precursor material of Zr-PILC. Chemical composition of Montmorillonite $\mathrm{K} 10$ is $69.0 \% \mathrm{SiO} 2,14.0 \% \mathrm{Al} 2 \mathrm{O} 3,4.50 \% \mathrm{Fe} 2 \mathrm{O} 3,2.0 \% \mathrm{MgO}, \% 1.5 \mathrm{CaO}$, $<0.5 \% \mathrm{Na} 2 \mathrm{O}, 1.5 \% \mathrm{~K} 2 \mathrm{O}$, and $7.0 \%$ loss on ignition. $\mathrm{K} 10$ has a surface area of $197 \mathrm{~m} 2 / \mathrm{g}$ and cation exchange capacity of K10 is 30 meq/ 100g. BET surface area (SBET) of Zr- K10 was obtained from $\mathrm{N} 2$ adsorption- desorption isotherms at $77 \mathrm{~K}$, measured on SORPTOMATIC 1990 after a degassing under vacuum for $3 \mathrm{~h}$ at $150{ }^{\circ} \mathrm{C}$ by using MILES-200 Advanced Data Processing Sorption Software Version 3.00. Zr- K10 has a surface area of $237.08 \mathrm{~m} 2 / \mathrm{g}$.

\subsection{Synthesis of Zirconium Pillared Montmorillonite K10 (Zr-K10)}

$\mathrm{Zr}-\mathrm{K} 10$ was prepared from zirconyl chloride solution. In a first set of preparation, 0.2 $\mathrm{M} \mathrm{ZrOCl} 2.8 \mathrm{H}_{2} \mathrm{O}$ solution was previously refluxed at $95{ }^{\circ} \mathrm{C}$ for 5 and $24 \mathrm{~h}$. The solution refluxed for $5 \mathrm{~h}$ remained limpid, but it turned turbid after refluxing for $24 \mathrm{~h}$. The solutions were added dropwise to $2 \mathrm{wt} \%\left(\% 50\right.$ acetone $\left.\% 50 \mathrm{H}_{2} \mathrm{O}\right)$ suspension of $\mathrm{K} 10$ at a rate of 10 mequiv. $\mathrm{Zr} \mathrm{g}^{-1}$ clay. The final suspensions were stirred for $24 \mathrm{~h}$ at room temperature. Samples were further aged for 10 days. The pillared clays were washed by dialysis and oven-dried. After this period, the samples were calcined at $250{ }^{\circ} \mathrm{C}$ for $2 \mathrm{~h}$.

\subsection{Preparation of the Superabsorbent Composite}

The poly (acrylic acid)/Zr-pillared clay superabsorbent composites were synthesized through the graft copolymerization of acrylic acid on pillared clay with MBA as a crosslinker and APS as an initiator in an aqueous solution. The inorganic pillared clay particles in the 
network acted as additional network points (Li et al., 2004). Acrylic acid (20 g) was neutralized with potassium hydroxide solution (12.1 g $\mathrm{KOH}+10.0 \mathrm{~g} \mathrm{H}_{2} \mathrm{O}$ ). After the neutralization, MBA solution $\left(0.013 \mathrm{~g} \mathrm{MBA}+3.0 \mathrm{~g} \mathrm{H}_{2} \mathrm{O}\right)$ was added to the monomer solution. The mixture was poured into a $600-\mathrm{mL}$ beaker, which was equipped with a magnetic stirrer and thermometer. $0.05,0.10$ and $0.20 \mathrm{~g}$ of $\mathrm{Zr}-\mathrm{K} 10$ were added to monomer solutions and stirring was continued until homogeny mixtures were obtained. To start polymerization reaction, the APS solution ( $0.05 \mathrm{~g}$ APS $+1.5 \mathrm{~g} \mathrm{H}_{2} \mathrm{O}$ ) and the SMBS solution (0.063 $\mathrm{g}$ SMBS + $2 \mathrm{~g} \mathrm{H}_{2} \mathrm{O}$ ) were added to the mixture. The temperature of mixture was increase rapidly to almost $100^{\circ} \mathrm{C}$ within a few minutes. Prior to hardening the products, the mixtures were pour into the Petri dish to obtain thin films. Samples were dried in a vacuum oven at $70^{\circ} \mathrm{C}$ for $24 \mathrm{~h}$ and then a few amount of water was dropped to film and after $1 \mathrm{~h}$, the film was removed from Petri dish and dried again.

\subsection{Measurement of Water Absorbency}

Water absorbency measurement was performed weighing dry sample $\left(m_{0}\right)$ and waterswollen sample at time $\mathrm{t}\left(m_{t}\right)$ at room temperature, respectively. The percent of swelling values were determined from the following equation (El Hamshary, 2007).

$\%$ Swelling $=100\left[\frac{\left(m_{t}-m_{0}\right)}{m_{0}}\right]$

The swelling measurements were made thrice and the average data was used for calculations.

\subsection{Measurement of the Swelling Rate}

Dry film superabsorbents composite samples were firstly weighed and then immersed in $20 \mathrm{~mL}$ of distilled water at room temperature. The weighing swelling ratios of samples were performed at various times. The swelling ratios of superabsorbents were calculated by equation (1). Swelling equilibrium times were determined via this process.

\subsection{Characterization of Pillared Clays and Zr-K10 Based Superabsorbents}

Fourier transform infrared (FTIR) spectra were recorded on a FTIR Perkin Elmer Spectrum BX-II in the 4000-400 cm-1 region using $\mathrm{KBr}$ pellets for pillared clays and ATR probe for superabsobent films. Morphology of the samples was examined using a Jeol JSM 60 SEM operating at the accelerating voltage of $20 \mathrm{kV}$ after coating the sample with a gold film. X-ray powder diffraction patterns were obtained by Rigaku Dmax 2200/ PC model instrument with $\mathrm{Cu} \mathrm{K}$ radiation $(40 \mathrm{kV}, 40 \mathrm{~mA})$. XRD measurements of superabsorbents were performed by film form. For clays and pillared clays, analysis was process to powder form. The change of clay layer space by pillaring and preparing superabsorbents was found out by means of Bragg equation $(2 \mathrm{~d} \sin \theta=n \lambda)$. XRD reveals the basal spacing of the pillared clays before and after in-situ incorporation indicating the morphology of the superabsorbent (exfoliated, intercalated or only dispersed).

\section{RESULTS AND DISCUSSION}

\subsection{Swelling Rate Measurements}

Figure 1 displays the swelling rate of Zr-K10 based superabsorbents. It was found that the swelling ratio of superabsorbent hydrogel containing $0.05 \mathrm{~g}$ of $\mathrm{Zr}-\mathrm{K} 10$ was higher than superbsorbents containing 0.10 and $0.20 \mathrm{~g}$ of $\mathrm{Zr}-\mathrm{K} 10$ at swelling equilibrium, respectively.

Additionally, the swelling rate of Zr-K10 (0.05g)-SA was the highest than the others and the time needing to reach swell equilibrium increases with increase of pillared clay amount. Zr-K10 based superabsorbents reached equilibrium at about $120 \mathrm{~min}$. The percentages of equilibrium swelling values were at about 12500 for $\mathrm{Zr}-\mathrm{K} 10(0.05 \mathrm{~g})$-SA, at 
about 11500 for Zr-K10 (0.10g)-SA and at about 10850 for Zr-K10 (0.20g)-SA. This may be attributed to crosslink density and elasticity of polymer network. Pillared clay act as crosslinking points because of carrying $-\mathrm{OH}$ groups in their structure. The carboxylate groups of the polyacrylate chains may react with $-\mathrm{OH}$ groups of pillared clays. Increasing the amount of pillared clays in the polymeric network resulted in the generation of more crosslink points that increase the crosslink density of the composite, and then the elasticity of the polymer chains decrease. It was deduced that more crosslink points may occur between $\mathrm{Zr}$ K10 $(0.20 \mathrm{~g})$ pillared clay and SA. Shortly, the superabsorbent with lower pillared clay content had a higher initial swelling rate and higher water absorbency and required less time to reach swelling equilibrium.

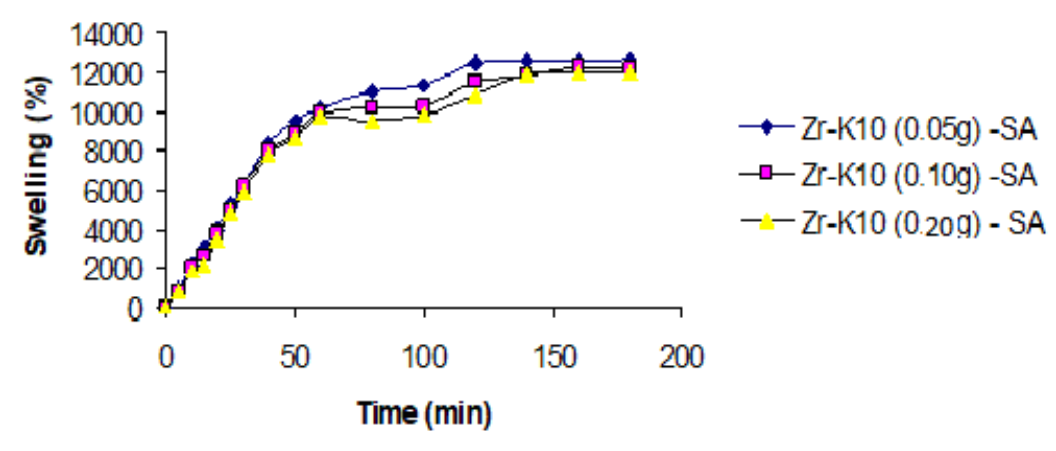

Figure 1. Swelling kinetics of superabsorbents composite in distilled water

\section{2. pH-Sensitivity of the Superabsorbents}

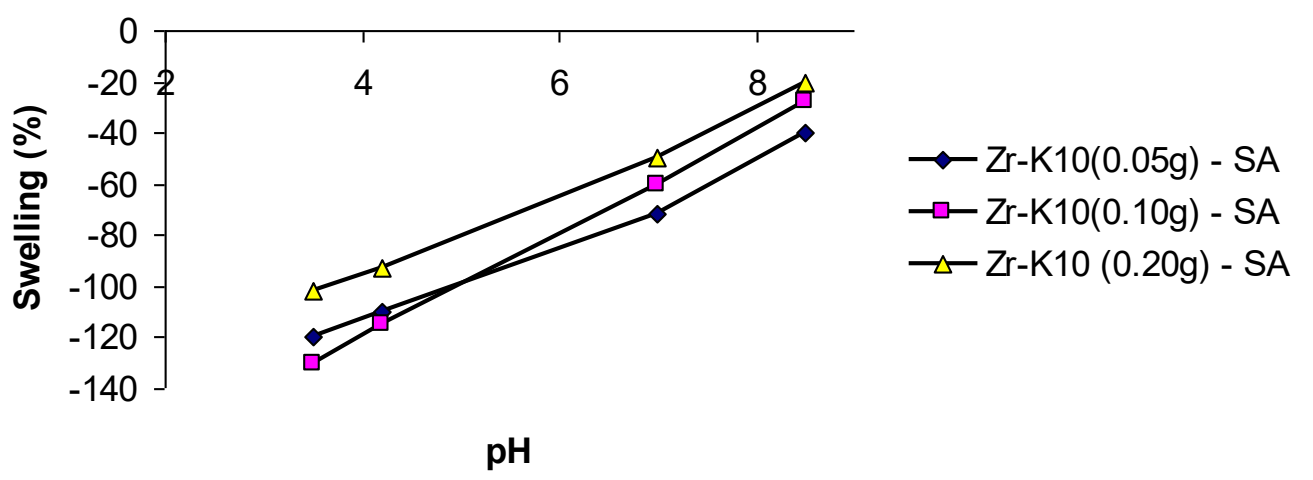

Figure 2. Effect of $\mathrm{pH}$ on the equilibrium swelling of superabsorbents

To reveal $\mathrm{pH}$ sensitivity of pillared clay based superabsorbents, firstly the films were immersed in distilled water and then in different buffer solutions until swelling equilibrium. Figure 2 showed the effect of the $\mathrm{pH}$ on water absorbency of superabsorbents. The buffer solutions at $\mathrm{pH} 3.5,4.2,7.0$ and 8.5 were prepared by using citric acid and $\mathrm{Na}_{2} \mathrm{HPO}_{4} \cdot 2 \mathrm{H}_{2} \mathrm{O}$ solutions. The absorbency of the superabsorbent composite increased sharply as the $\mathrm{pH}$ increased from 3.5 to 8.5. The superabsorbent composites were sensitive to the $\mathrm{pH}$ change. Shrinkage was occurred at acidic $\mathrm{pH}$ for all $\mathrm{Zr}-\mathrm{K} 10$ based superabsorbents. The change in the swelling ratio by changing $\mathrm{pH}$ may be explained by Lee and Wum suggestion (Lee, Wum, 1996); in an acidic environment, the $-\mathrm{COO}^{-}$groups on the polymeric chains turn into - $\mathrm{COOH}$ groups, while the $-\mathrm{COOH}$ groups on the polymeric chain turn into $-\mathrm{COO}^{-}$groups in basic 
solutions, and this behavior was interpreted as a buffer action of $-\mathrm{COOH}$ and $-\mathrm{COO}^{-}$. In the acidic environment, the repulsion between polymeric chains decreases, which leads to the decrease of water absorbency. The $-\mathrm{COOH}$ groups present within the network remain almost nonionized, thus imparting almost non-polyelectrolyte type behavior to the hydrogel (ElHamsary, 2007). Furthermore, there exist H-bonding interactions between carboxylic groups of acrylic acid and amide groups of acrylamide. These H-bonding interactions result in the formation of a compact or tight structure which does not permit much movement of polymeric chains within the hydrogel network, which lead to minimum swelling of hydrogel (ElHamsary, 2007). The ionization of the carboxylic acid groups of the gel occurred. More hydrophilic polymer was occurred at higher $\mathrm{pH}$ value because of ionization of the carboxylic acid group and contributed to the higher water absorption. As seen in Figure 2, the swelling behavior of Zr-K10 based superabsorbent films seem to be $\mathrm{pH}$ dependent. The content of pillared clay in the network of the superabsorbent affected the swelling ratio. More shrinkage and lower swelling was obtained by increasing the content of Zr-K10 in the polymeric network. Additionally, crosslinking might be increased in order of increasing the amount of pillared clay. The water content decreased due to increased level of crosslinking (Wu et al., 2003).

\subsection{Swelling Reversibility of Superabsorbents}

To clarify swelling reversibility, the Zr-K10 based superabsorbents were equilibrated at $\mathrm{pH}=1.2$, and then alternated between solutions at $\mathrm{pH}=7.4$ and $\mathrm{pH}=1.2$ for about 120 minutes, respectively. A swelling was measured at about $910 \%$ for Zr-K10 (0.05g)-SA, $290 \%$ for Zr$\mathrm{K} 10(0.10 \mathrm{~g})-\mathrm{SA}$ and $230 \%$ for $\mathrm{Zr}-\mathrm{K} 10(0.20 \mathrm{~g})-\mathrm{SA}$ at $\mathrm{pH}=7.4$, respectively. Then the films put into $\mathrm{pH}=1.2$ for $120 \mathrm{~min}$. and approximately $12.0 \%, 42.0 \%$ and $142.0 \%$ deswellings for $\mathrm{Zr}-\mathrm{K} 10(0.05 \mathrm{~g})-\mathrm{SA}, \mathrm{Zr}-\mathrm{K} 10(0.10 \mathrm{~g})-\mathrm{SA}$ and Zr-K10(0.20g)-SA, respectively were determined. Besides, when the superabsorbent films altered from acidic to basic buffer and then to acidic buffer, pillared clay based superabsorbents showed a reversible swelling behavior with relatively fast response. $\mathrm{Zr}-\mathrm{K} 10(0.05 \mathrm{~g})-\mathrm{SA}$ had the fastest response to $\mathrm{pH}$ change. It can be added that reversible swell-shrink properties of pillared clay based superabsorbents would be beneficial characteristics for $\mathrm{pH}$ sensitive systems with controllable swelling ability. Also, this result indicates that the PAMA composite can be used as a recyclable water-managing material for the renewal of arid and desert environment (Zhang et al., 2006).

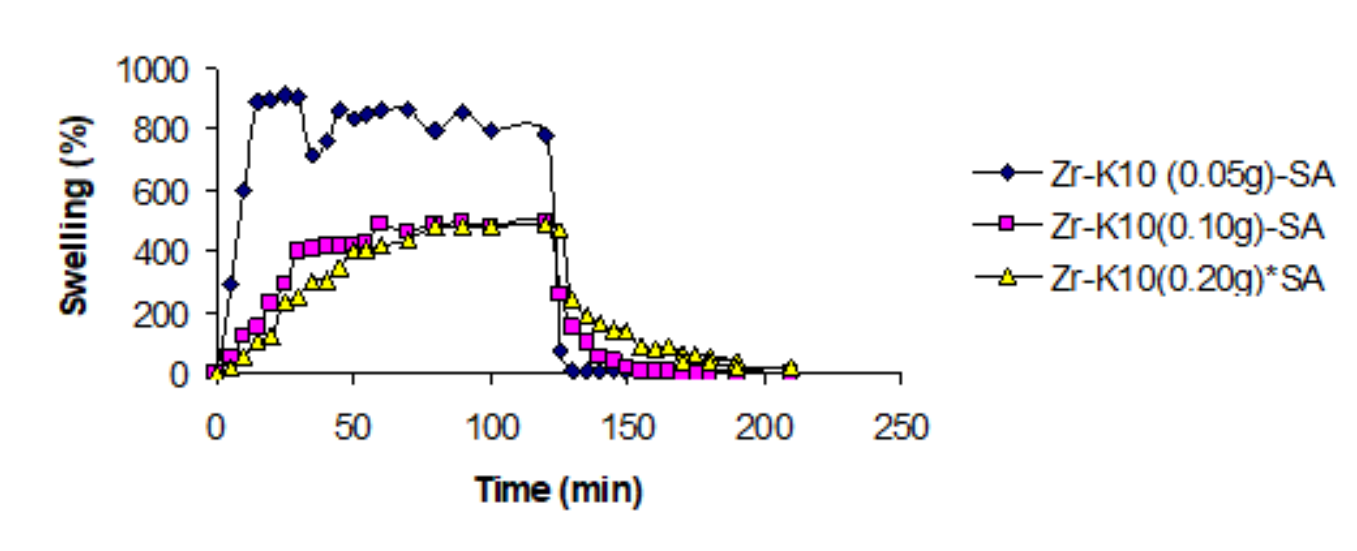

Figure 3. $\mathrm{pH}$-dependent reversible swelling behavior of superabsorbents (Superabsorbents equilibrated at $\mathrm{pH}=1.2$, then alternated between solutions at $\mathrm{pH}=7.4$ and $\mathrm{pH}=1.2$ )

Concentration set design for the preparation of PCR and PLS calibrations 


\subsection{SEM Images}

The SEM micrographs of Zr-K10, Zr-K10 (0.05g)-SA, Zr-K10 (0.10g)-SA and ZrK10 (0.20 g)-SA were exhibited in Figure 4. A considerable difference was observed between pillared clay and superabsorbents. Polymeric network was predominant in superabsorbent hydrogel morphology. When the content of pillared clay was increased, the surface of polymeric network was affected, the signs of pillared clay were increased and surface of hydrogels were less smooth. Also SEM micrographs were supported the homogeneity of composed superabsorbents after graft polymerization had been occurred. Homogenous dispersion of pillared clay particles may be contributed to more crosslinking structure. Furthermore more crosslinking might be obtained by increasing pillared clay amount in the superabsorbents. SEM micrographs of superabsorbents clearly represented lower swelling capacities because of their highly rigid type structure.

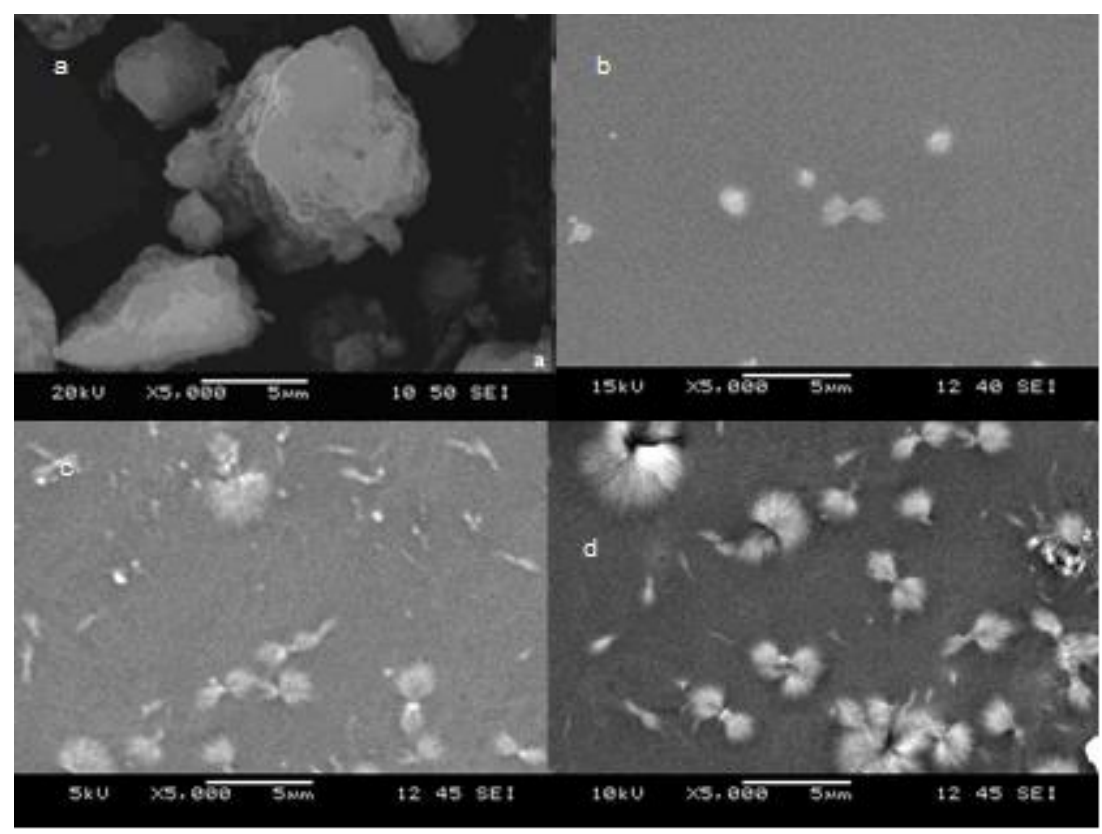

Figure 4. SEM micrographs of (a)Zr-K10 (b)Zr-K10(0.05g)-SA (c)Zr-K10(0.10g)-SA (d) Zr$\mathrm{K} 10(0.20 \mathrm{~g})-\mathrm{SA}(5000 \mathrm{x}$ magnification).

\subsection{FT-IR Analysis}

Clays - pillared clays and superabsorbents were analysed by using $\mathrm{KBr}$ disks and ATR prope, respectively. Consequently the characteristic FTIR bands of clays and superabsorbent composites were summarized in Table 1. 
Table 1. The characteristic FT-IR data of the samples

\begin{tabular}{|c|c|c|c|c|c|}
\hline \multirow[t]{2}{*}{ IR bands } & & \multicolumn{4}{|c|}{ Samples } \\
\hline & K10 & $\begin{array}{l}\text { Zr- } \\
\text { K10 }\end{array}$ & $\begin{array}{l}\text { Zr-K10(0.05g)- } \\
\text { SA }\end{array}$ & $\begin{array}{l}\text { Zr-K10(0.10g)- } \\
\text { SA }\end{array}$ & $\begin{array}{l}\mathrm{Zr}-\mathrm{K} 10(0.20 \mathrm{~g})- \\
\text { SA }\end{array}$ \\
\hline $\mathrm{Al}_{2} \mathrm{OH}$ (octahedral layer) $\left(\mathrm{cm}^{-1}\right)$ & 3654 & 3650 & 3645 & 3642 & 3652 \\
\hline $\begin{array}{l}\text { Stretching vibrations of } \\
\mathrm{H}_{2} \mathrm{O}\left(\mathrm{cm}^{-1}\right)\end{array}$ & 3410 & 3420 & 3398 & 3450 & 3420 \\
\hline $\begin{array}{l}\text { Stretching vibration of }-\mathrm{CH}_{2} \\
\left(\mathrm{~cm}^{-1}\right)\end{array}$ & & & $2980-2870$ & $2970-2862$ & $2982-2871$ \\
\hline $\begin{array}{l}\text { Stretching vibration of } \mathrm{C}=\mathrm{O} \\
\left(\mathrm{cm}^{-1}\right)\end{array}$ & & & 1732 & 1725 & 1745 \\
\hline $\begin{array}{l}\text { Bending vibrations of } \mathrm{H}_{2} \mathrm{O}\left(\mathrm{cm}^{-}\right. \\
\left.{ }^{1}\right)\end{array}$ & 1636 & 1630 & 1678 & 1685 & 1638 \\
\hline $\begin{array}{l}\text { Asymmetric vibration of R- } \\
\text { COOK }\left(\mathrm{cm}^{-1}\right)\end{array}$ & & & 1554 & 1550 & 1538 \\
\hline $\begin{array}{l}\text { Bending vibration of }-\mathrm{CH}_{2}\left(\mathrm{~cm}^{-}\right. \\
\left.{ }^{-}\right)\end{array}$ & & & 1457 & 1450 & 1445 \\
\hline $\begin{array}{l}\text { Symmetric vibration of R- } \\
\text { COOK }\left(\mathrm{cm}^{-1}\right)\end{array}$ & & & 1412 & 1405 & 1402 \\
\hline $\begin{array}{l}\text { Asymmetric stretching } \\
\text { vibrations of } \mathrm{SiO}_{2} \\
\text { tetrahedra }\left(\mathrm{cm}^{-1}\right)\end{array}$ & 1045 & 1040 & 1075 & 1072 & 1070 \\
\hline $\begin{array}{l}\text { Bending vibrations of } \\
\mathrm{Al}_{2} \mathrm{OH}\left(\mathrm{cm}^{-1}\right)\end{array}$ & 917 & 921 & 915 & 917 & 913 \\
\hline & 842 & 843 & & & \\
\hline $\begin{array}{l}\text { Stretching vibration of } \mathrm{Al}^{\mathrm{IV}} \\
\text { tetrahedra }\left(\mathrm{cm}^{-1}\right)\end{array}$ & 798 & 800 & 802 & 800 & 805 \\
\hline & 673 & 692 & & & \\
\hline & 615 & & & & \\
\hline & 590 & & & & \\
\hline $\begin{array}{l}\text { Bending vibration of } \mathrm{Si}-\mathrm{O}\left(\mathrm{cm}^{-}\right. \\
\left.{ }^{1}\right)\end{array}$ & $\begin{array}{l}524 \\
468\end{array}$ & $\begin{array}{l}525 \\
469\end{array}$ & $\begin{array}{l}520 \\
480\end{array}$ & $\begin{array}{l}524 \\
470\end{array}$ & $\begin{array}{l}525 \\
465\end{array}$ \\
\hline
\end{tabular}

A broader band around $3620 \mathrm{~cm}-1$ for all samples, in the $-\mathrm{OH}$ stretching region are attributed to $\mathrm{Al} 2 \mathrm{OH}$ group $(3650 \mathrm{~cm}-1)$ of the octahedral layer. Stretching vibrations of water molecules may also contribute to $-\mathrm{OH}$ peaks $(3500 \mathrm{~cm}-1)$. On pillaring, the band broadens due to the introduction of more $-\mathrm{OH}$ groups of the pillar, which is interpreted as an effect of pillaring. The broad absorption bands observed in $\mathrm{K} 10, \mathrm{Zr}-\mathrm{K} 10$ and $\mathrm{Zr}-\mathrm{K} 10$ containing superabsorbents at $3410,3420,3398,3450$ and $3420 \mathrm{~cm}-1$, respectively represents the fundamental stretching vibrations of different $-\mathrm{OH}$ groups present in $\mathrm{Mg}-\mathrm{OH}-\mathrm{Al}, \mathrm{Al}-\mathrm{OH}-$ $\mathrm{Al}$ and $\mathrm{Fe}-\mathrm{OH}-\mathrm{Al}$ units in the octahedral layer. The shift of these bands is also observed for $\mathrm{Zr}-\mathrm{K} 10$ based composites. The other explaining for this is that the networks of superabsorbents contain pillared clays and the graft copolymerization between $\mathrm{OH}$ groups on clays and monomers take place during the reaction. Bands around $1600 \mathrm{~cm}-1$ are due to bending vibrations of water. The band around $1045 \mathrm{~cm}-1$ is due to asymmetric stretching vibrations of $\mathrm{SiO} 2$ tetrahedra. After polymerization, stretching vibrations of $\mathrm{SiO} 2$ tetrahedra was shifted to around $1075 \mathrm{~cm}-1$ for Zr-K10 based composites, respectively. It indicates the esterification of carboxylic acid with silanol. This mechanism was supported by shifting of the $\mathrm{OH}$ stretching vibration of clays and pillared clays. These results may confirm the grafting 
reaction between pillared clays and the acrylic network through ester formation. A band around $800 \mathrm{~cm}-1$ is due to stretching vibration of AlIV tetrahedra, when substitution of $\mathrm{Al}$ for $\mathrm{Si}$ is low; $\mathrm{Al} 2 \mathrm{OH}$ libration lies in the $915 \pm 950 \mathrm{~cm}-1$ range, and absorption at $526-469 \mathrm{~cm}-1$ is due to bending of $\mathrm{Si}-\mathrm{O}$ vibration. These IR characteristic bands of clay were observed and only little shifts of were noticeable in pillared clays and the network of pillared clay based composites from Table1. The little shifts of these all bands showed that the basic clay layer structure remains unaffected on pillaring and polymerization. These results suggested that the pillaring agents physically entrapped within the PILC structure.

The FTIR data gave a distinct absorption band at about $1730 \mathrm{~cm}-1$ for only composites. This band was belong to the $\mathrm{C}=\mathrm{O}$ stretching vibration. The bands corresponding to the $-\mathrm{C}-\mathrm{H}$ stretching of acrylate unite was observed around 2980 and $2870 \mathrm{~cm}-1$ for composites. The bands at around $1450 \mathrm{~cm}-1$ were attributing to the bending vibration bands of $-\mathrm{CH} 2$ for composites. Asymmetric and symmetric vibrations of R-COOK groups appear at about 1550 and $1040 \mathrm{~cm}-1$ for the superabsorbents. Eventually ester formation is occurred by graft polymerization reaction.

\subsection{XRD Analysis}

The X-ray diffraction patterns of Zr-K10, Zr-K10 (0.05g)-SA, Zr-K10 (0.10g)-SA and $\mathrm{Zr}-\mathrm{K} 10(0.20 \mathrm{~g})-\mathrm{SA}$ were performed. The lattice spacings of montmorillonite $\mathrm{K} 10$ and $\mathrm{Zr}$ pillared K10 were summarized in Table 2. 001 lattice spacing of K10 was increasing by pillaring with $\mathrm{Zr}$ polyoxications. After polymerization with pillared clays the diffraction peak corresponding to the montmorillonite (d001 basal spacing of montmorillonite layers) was not observed at about $2 \square=5.0-6.0^{\circ}$. The absence of this peak indicates that the montmorillonite layers are exfoliated or highly expanded. The expansion mechanism probably originates from the growing polymer chains by adsorbed monomers on the clay layers pushing apart the layers even in high clay loadings. Layers of montmorillonite were completely dispersed in a continuous polymer matrix as single layers.

Table 2. XRD results of montmorillonite $\mathrm{K} 10$ and $\mathrm{Zr}-\mathrm{K} 10$

\begin{tabular}{lll}
\hline & \multicolumn{2}{c}{ Samples } \\
& $\mathrm{K} 10$ & $\mathrm{Zr}-\mathrm{K} 10$ \\
\hline $2 \theta$ & $5.94^{\circ}$ & $5.21^{\circ}$ \\
$\mathrm{d}_{001}(\AA)$ & 14.83 & 16.93 \\
$\mathrm{~d}_{001}-9.6(\AA)$ & - & 7.33 \\
\hline
\end{tabular}

\section{CONCLUSION}

In this present study, swelling characters of composites were revealed out after grafting occurred between pillared clays and the acrylic network. It was found that swelling degree and fast response to $\mathrm{pH}$ change of the pillared clay based superabsorbent hydrogels was decreasing by increasing the content of the pillared clay in the network of the hydrogel. The swelling rate of Zr-K10 (0.05g)-SA was higher than Zr-K10 (0.10 g)-SA and Zr-K10 $(0.20 \mathrm{~g})$-SA. Additionally, the time needed to reach swelling equilibrium decreased with decrease of pillared clay content. The swelling values of superabsorbents were significantly increased with the raise of $\mathrm{pH}$ in the range $3.5-8.5$.

FTIR analysis and SEM micrographs impressed that the pillared clay based superabsorbents were successfully obtained. Besides, XRD analysis of the samples showed 
that layers of montmorillonite were exfoliated in the hydrogel structure and were completely dispersed in a continuous polymer matrix as single layers.

Clays and pillared clays might be added to superabsorbent hydrogel to compose economic products. Modifying of poly (acrylic acid) composites with inorganic materials affected the swelling character and product cost. Decreasing of swelling ratio was observed by increasing the content of pillared clay. All Zr- K10 based poly (acrylic acid) composites were $\mathrm{pH}$ sensitive. The behavior of shrinkage at acidic and swelling at basic environment was useful for $\mathrm{pH}$ sensitive systems with controllable swelling ability such as controllable drug delivery. Also, the character of water absorbing and swelling reversibility was indicator of suitable applications in agriculture and horticulture. 


\section{REFERENCES}

CHENG, L.S., YANG, R.T., (1997), Tailoring micropore dimensions in pillared clays for enhanced gas adsorption, Microporous Materials 8: 177-186.

EL-HAMSHARY, H., (2007), Synthesis and water sorption studies of $\mathrm{pH}$ sensitive poly(acrylamide-co-itaconic acid) hydrogels, European Polymer Journal, 43: 4830 4838 .

FIGUERAS, F., (1988), Pillared clays as catalysts, Catalysis Reviews 30: 457 - 499.

GIL, A., GANDIA, L.M., VICENTE, M.A., (2000), Recent Advances in the Synthesis and Catalytic Applications of Pillared Clays, Catalysis Reviews - Science and Engineering, 42: 145-212

LEE, W.F., WUM, R.J., (1996), Superabsorbent polymeric materials. 1. Swelling behaviors of crosslinked poly(sodium acrylateco- hydroxyethyl methacrylate) in aqueous salt solution, J. Appl. PolYM. SCI., 62: 1099-1114.

LIN, J., WU, J., YANG, Z., PU, M., (2001), Synthesis and properties of poly(acrylic acid)/mica superabsorbent nanocomposite, Macromol Rapid Commun, 22: 422-424.

LI, A., WANG, A.Q., CHEN, J.M., (2004), Studies on poly (acrylic acid)/attapulgite superabsorbent composite. I. Synthesis and characterization, J Appl Polym Sci, 92: 1596-1603.

VAUGHAN, D.E.W., (1988), Pillared clays - a historical perspective, Catalysis Today, 2:187-198.

WANG, W., ZHENG, Y. and WANG, A., 2008, Syntheses and properties of superabsorbent composites based on natural guar gum and attapulgite, Polymers For Advanced Technologies, 19: 1852-1859.

WEAVER, M.O., BAGLEY, E.B., FANTA, G.F., DOANE, W.M., (1976), Highly absorbent starch-containing polymeric compositions, US Patent, 3,981,100.

WU, J., LIN. J., ZHOU, M., WEI, C., (2000), Synthesis and properties of starch-graftpolyacrylamide/clay superabsorbent composite, Macromol. Rapid Commun, 21: 10321034.

WU, J.H., WEI, Y.L., LIN, S.B., (2003), Study on starch-graft-acrylamide/mineral powder superabsorbent composite, Polymer, 44: 6513-6520.

ZHANG, J.P., CHEN, H., WANG, A.Q., (2006), Study on superabsorbent composite-VII. Effects of organification of attapulgite on swelling behaviors of poly (Acrylic acid-coacrylamide)/sodium humate/organo-attapulgite composite, Polymers for Advanced Technologies, 17: 379-385. 